\title{
EVALUASI PENEGAKAN HUKUM PIDANA PEMILU DALAM PENYELENGGARAAN PEMILU 2019
}

\author{
Muhammad Nur Ramadhan \\ Badan Pengawas Pemilihan Umum Republik Indonesia \\ Jalan M.H. Thamrin No. 14 Jakarta Pusat \\ mnr.mnuramadhan@gmail.com
}

\begin{abstract}
This paper will analyze the implementation of alleged treatment of election crimes in the implementation of election 2019. There are several weaknesses in the handling of alleged election crimes through the Integrated Law Enforcement Center (Sentra GAKKUMDU), first related to differences in understanding among the elements in Sentra Gakkumdu and both patterns of relations between Sentra Gakkumdu, become One of the obstacles indicators in election criminal law enforcement. On the other hand, there are challenges that should be promptly responded in the future democracy process, which is about the electoral law enforcement through the Sentra Gakkumdu which is still a big question in Democracy journey in Indonesia. Findings in the election 2019, there is a weakness of the electoral law enforcement, it is reflected in some cases that are handled through the Sentra Gakkumdu namely the termination of the declaration of Governor and 5 (five) regional head supports one of the presidential candidate in West Sulawesi (Sulbar) and the termination of cases of alleged violations in the stage of the campaign conducted by 12 (twelve) regional head in West Sumatera (Sumbar). Both cases can be the benchmark to evaluate the law enforcement in the implementation of the 2019 election. Analysis in this study was written based on a quality study with a juridical approach, which is to look at a series of primary legal resources in the form of legislation, other regulations related to political parties, both from aspects Institutional and implementation of elections. In addition, this study also considers secondary legal resources in the form of related literature, with the information provided from other relevant news sources. This analysis is expected to describe in detail the problem of the electoral law in the elections faced in the 2019 election and can be the answer to the problem.
\end{abstract}

Keywords: criminal law enforcement, election 2019, sentra gakkumdu. 


\begin{abstract}
Abstrak
Tulisan ini akan menganalisa pelaksanaan penanganan dugaan tindak pidana pemilu dalam penyelenggaraan pemilu serentak 2019. Terdapat beberapa kelemahan dalam penanganan dugaan tindak pidana pemilu melalui Sentra Penegakkan Hukum Terpadu (Sentra Gakkumdu), pertama terkait perbedaan pemahaman antar unsur dalam Sentra Gakkumdu dan kedua pola hubungan antara Sentra Gakkumdu yang menjadi salah satu indikator halangan dalam penegakan hukum pidana pemilu. Disisi lain, terdapat tantangan yang harus segera direspon dalam proses demokrasi kedepan, yakni mengenai penegakkan hukum pemilu melalui Sentra Gakkumdu yang masih menjadi pertanyaan besar dalam perjalanan demokrasi di Indonesia. Temuan dalam pemilu 2019, terdapat dinamika yang terjadi dalam penegakkan hukum pemilu, hal tersebut tercermin dalam beberapa contoh kasus yang ditangani melalui Sentra Gakkumdu yakni penghentian kasus deklarasi Gubernur dan 5 (lima) kepala daerah mendukung salah satu paslon presiden di Sulawesi Barat (Sulbar) dan penghentian kasus dugaan pelanggaran pada tahapan kampanye yang dilakukan oleh 12 (dua belas) kepala daerah di Sumatera Barat (Sumbar). Kedua kasus tersebut dapat menjadi tolak ukur untuk mengevaluasi penegakkan hukum dalam penyelenggaraan Pemilu 2019. Analisa dalam penelitian ini ditulis berdasarkan kajian kualititatif dengan pendekatan yuridis, yaitu melihat kepada serangkaian sumber hukum primer berupa peraturan perundang-undangan, peraturan lain yang terkait dengan partai politik, baik dari aspek kelembagaan maupun pelaksanaan Pemilu. Selain itu, kajian ini juga mempertimbangkan sumber hukum sekunder berupa literatur yang terkait, dengan dilengkapi informasi dari sumber pemberitaan lain yang relevan. Analisa ini diharapkan dapat menjabarkan secara rinci permaslahan penegakkan hukum Pemilu yang dihadapi pada Pemilu 2019 dan dapat menjadi jawaban atas permasalahan yang ada.
\end{abstract}

Kata Kunci : pemilu 2019, penegakkan hukum pidana, sentra gakkumdu. 


\section{Pendahuluan}

Sebagai konsekuensi dari negara hukum dengan demikian bahwa setiap sikap, kebijakan dan perilaku alat negara serta penduduk harus berdasarkan atas hukum. Begitu pula dengan hal-hal yang menyangkut kegiatan penindakan terhadap setiap pelanggaran perkara pidana pemilihan umum atau penyimpangan terhadap peraturan perundang-undangan pemilu melalui proses pidana yang melibatkan peran dari pada aparat penegak hukum Badan Pengawas Pemilu (Bawaslu), Komisi Pemilihan Umum (KPU), Kepolisian, Kejaksaan, Pengadilan dan Lembaga Pemasyarakatan (LP). (Achmad Sulchan, 2014)

Pemillihan Umum (pemilu) pada hakekatnya adalah sarana kedaulatan rakyat, sehingga tidak satu pun negara di dunia ini yang mengklaim dirinya sebagai negara demokratis yang tidak menyelenggarakan Pemilu. Pemilu dihadirkan sebagai instrumen untuk memastikan adanya transisi dan rotasi kekuasaan berjalan demokratis. Selain itu, Pemilu juga merupakan sarana untuk mendorong akuntabilitas dan kontrol publik terhadap negara. Haywood menjelaskan fungsi pemilu dari dua arah: bottom-up dari masyarakat terhadap negara, dan top-down dari negara terhadap masyarakat. (Tim Pengkajian Hukum BPHN, 2015)

Untuk menjamin pemilihan umum yang bebas dan adil diperlukan perlindungan bagi para pemilih, maupun bagi rakyat umumnya dari segala ketakutan, intimidasi, penyupan, penipuan, dan praktek-praktek curang lainnya, yang akan mempengaruhi kemurnian hasil pemilihan umum. Salah satu syarat pokok demokrasi adalah adanya sistem pemilihan umum yang jujur dan adil (free and fair elections). Pemilu jujur dan adil dapat dicapai apabila tersedia perangkat hukum yang mengatur proses pelaksanaan pemilu; sekaligus melindungi para penyelenggara, kandidat, pemilih, pemantau, dan warga negara pada umumnya dari ketakutan, intimidasi, kekerasan, penyuapan, penipuan, dan berbagai praktik curang lainnya yang akan mempengaruhi hasil pemilu. Oleh karena itu, pemilu yang jujur dan adil membutuhkan peraturan perundang-undangan pemilu beserta aparat yang bertugas menegakkan peraturan perundang-undangan pemilu tersebut.

Sebaliknya, jika pemilihan dimenangi melalui cara-cara curang (malpractices), sulit dikatakan bahwa para pemimpin atau para legislator yang terpilih di parlemen merupakan wakil-wakil rakyat dan pemimpin sejati. Guna melindungi kemurnian pemilu yang sangat penting bagi demokrasi itulah para pembuat undang-undang telah menjadikan sejumlah perbuatan curang dalam pemilu sebagai suatu tindak pidana. Dengan demikian, undang-undang tentang pemilu di samping mengatur tentang bagaimana pemilu dilaksanakan, juga melarang sejumlah perbuatan yang dapat menghancurkan hakikat free and fair election itu serta mengancam pelakunya dengan hukuman. (Ramlan Surbakti, 2011)

Berdasarkan pengalaman praktik penyelenggaraan pemilu selama ini, munculnya masalah-masalah penegakan hukum pemilu tersebut disebabkan beberapa faktor: pertama, batasan terjaditidaknya pelanggaran tidak pasti sehingga 
menimbulkan multitafsir yang berujung pada kontroversi; kedua, mekanisme dan prosedur penanganan pelanggaran tidak jelas sehingga penanganannya pun tidak mudah; ketiga, lembaga penegak hukum pemilu tidak disiapkan dengan baik sehingga kedodoran dalam menangani kasus-kasus yang terjadi; keempat, sanksi hukum atas terjadinya pelanggaran sangat ringan sehingga tidak memberi efek jera. (Topo Santoso, 2006)

Permasalahan yang sama juga muncul dalam penanganan perkara tindak pidana pemilu. Dengan rentang waktu penanganan perkara yang relatif singkat, maka diharapkan setiap laporan dugaan terjadinya tindak pidana pemilu yang dilaporkan kepada Bawaslu dapat diproses dengan cepat guna menentukan terdapat atau tidaknya cukup dasar untuk meneruskan laporan tersebut kepada Kepolisian untuk dilakukan penyidikan. Namun demikian, dalam penerapannya sering kali terjadi perbedaan penafsiran terhadap kasus posisi serta ketentuan pidana yang diduga dilanggar, sehingga akhirnya banyak dugaan pelanggaran pemilu yang tidak dapat dilanjutkan karena lampaunya waktu penanganan yang ditentukan oleh Undang-Undang.

Undang-Undang Nomor 7 Tahun 2017 tentang Pemilihan Umum mengatur tentang pembentukan Sentra Penegakan Hukum Terpadu (Gakkumdu) dengan tujuan untuk menyamakan pemahaman dan pola penanganan tindak pidana pemilu antara Bawaslu, Kepolisian Negara Republik Indonesia, dan Kejaksaan Agung Republik Indonesia. Namun demikian dalam pelaksanaannya, masih sering timbul kendala klasik berupa ego sektoral dari unsur-unsur yang tergabung dalam Gakkumdu sehingga pada akhirnya menyebabkan terhambatnya pelaksanaan tugas-tugas yang dipercayakan kepada Gakkumdu.

Dalam tulisan ini, akan melakukan analisis terhadap evaluasi penegakan hukum pemilu dalam penyelenggaraan pemilu tahun 2019. Tulisan ini akan menyajikan alur berpikir dari beberapa subbab dalam bab pembahasan tulisan ini, adapun subbab tersebut adalah sebagai berikut:

- Tugas, kewenangan dan hambatan Sentra Gakkumdu dalam penegakan hukum pemilu;

- Dinamika dan Fakta penegakkan hukum Pemilu oleh Sentra Gakkumdu;

- Kritik terhadap mekanisme penanganan dugaan tindak pidana Pemilu dalam Pemilu 2019.

Sehingga diakhir tulisan ini akan menyajikan kesimpulan yang menggambarkan evaluasi dari penegakan hukum pemilu yang dilakukan dalam Pemilu Serentak 2019.

\section{Metode Penelitian}

Metode penelitian yang digunakan dalam artikel ini adalah sebagai berikut.

\subsection{Metode Pendekatan}

Artikel ini menggunakan pendekatan yuridis normatif (Soerjono Soekanto, 1986), yaitu menguji dan mengkaji data sekunder berupa hukum positif, azas-azas dan teori hukum, serta kaidah-kaidah hukum yang berhubungan dengan Hukum Kepemiluan dan bidang ilmu lain yang berkaitan dengan penegakkan hukum pemilu dan Sentra Gakkumdu.

\subsection{Spesifikasi Penelitian}

Spesifikasi penelitian ini bersifat deskriptif analitis, yaitu suatu penelitian 
yang bertujuan untuk menggambarkan dan menganalisis fakta-fakta mengenai keadaan objek yang diteliti secara sistematis, faktual, dan akurat dengan teori-teori hukum positif yang menyangkut permasalahan yang diteliti. (Maria S.W. Suamrdjono, 1989) Dalam tulisan ini penulis akan menggambarkan permasalahan yang timbul dalam penegakkan hukum pemilu. Kemudian, permasalahan tersebut dianalisis berdasarkan hukum positif yaitu UU Pemilu, mekanisme penegakkan hukum dalam penyelenggaraan Pemilu.

\subsection{Teknik Pengumpulan Data}

Penelitian ini dilakukan berdasarkan teknik studi kepustakaan (library research), studi internet (online research) dan studi lapangan (field research). Studi kepustakaan dan studi internet dilakukan untuk mengumpulkan data yang berupa:

a. Bahan hukum primer, yaitu bahan yang sifatnya mengikat masalahmasalah yang akan diteliti berupa peraturan perundang-undangan, (Ronny Hanitijo Soemitro, 1983) diantaranya yang akan digunakan dalam penelitian ini sebagai berikut:

1) Undang-Undang Dasar Republik Indonesia Tahun 1945;

2) Undang-Undang Nomor 7 Tahun 2017 Tentang Pemilihan Umum;

3) Peraturan Badan Pengawas Pemilihan Umum Nomor 31 Tahun 2018 Tentang Sentra Penegakkan Hukum Terpadu; dan

4) Peraturan perundang-undangan lainnya yang relevan.

b. Bahan hukum sekunder, yaitu bahan yang diperoleh dari bukubuku mengenai ketentuan hukum yang erat kaitannya dengan sumber hukum primer dan dapat menunjang dalam menganalisis dan memahami bahan hukum primer, seperti Naskah Akademik Undang-Undang, hasil-hasil penelitian, hasil karya dari hukum dan seterusnya, serta pendapat para ahli yang terhimpun dalam buku-buku hukum, khususnya mengenai hukum keimigrasian, maupun buku-buku keimigrasian non-hukum, makalah, artikel, jurnal serta bahan-bahan lain yang dapat memberikan penjelasan terhadap bahan hukum primer di atas.

c. Bahan hukum tersier seperti ensiklopedia dan kamus yang berkaitan dengan masalah-masalah yang akan dibahas. (Amirudin \& Zainal Asikin, 2004

\section{Perspektif Teori}

\subsection{Sistem Keadilan Pemilu}

Sistem keadilan pemilu merupakan instrumen yang penting untuk menegakan hukum dan menjamin sepenuhnya prinsip demokrasi melalui pemilihan umum yang bebas, jujur, dan adil. (Orozco-Henriquez, 2010) Berkenaan dengan pelaksanaan mekanismenya, sedikitnya terdapat tiga mekanisme yang digunakan dalam pelaksanaan sistem keadilan pemilu.

Ketiga mekanisme tersebut memiliki kekhasan yang berbeda, dua diantaranya memiliki kekhasan formal sedangkan sisanya berciri khas informal. Untuk lebih jelasnya, ketiga mekanisme sistem keadilan pemilu tersebut dapat dijabarkan sebagaimana berikut ini:

a. mekanisme formal atau korektif (misalnya mengajukan dan memproses gugatan pemilu): jika dilaksanakan, mekanisme ini akan 
menghasilkan keputusan untuk membatalkan, mengubah, atau mengakui adanya ketidakberesan dalam proses pemilu;

b. mekanisme penghukuman atau punitif (misalnya dalam kasus pelanggaran pidana): jika dilaksanakan, mekanisme ini akan menjatuhkan sanksi kepada pelanggar, baik badan maupun individu yang bertanggung jawab atas ketidakberesan tersebut, termasuk tanggung jawab (liability) pidana atau administratif terkait dengan pemilu; dan

c. mekanisme alternatif: mekanisme ini dapat dipilih oleh pihak-pihak yang bersengketa.

Sehingga pada esensinya dapat dijelaskan bahwa sistem keadilan pemilu menyiapkan mekanisme yang ditujukan untuk menanggulangi kesalahan/ kekeliruan atau bahkan kecurangan yang terjadi dalam proses pemilihan. Mekanisme-mekanisme tersebut sangat berpengaruh dalam melindungi legitimasi pemilihan umum dalam hal terjadi kekeliruan ataupun kecurangan.

Berkenaan dengan hal tersebut, diperlukan lembaga yang menjadi pelaksana dari sistem keadilan pemilu untuk menangani gugatan yang timbul. Kembali merujuk pada hasil studi International IDEA atas modelmodel lembaga yang berperan dalam melaksanakan peradilan pemilu, maka secara sederhana dapat dikatakan bahwa Bawaslu sebagai penyelenggara Pemilu dapat dikategorikan sebagai lembaga yang menjalankan tujuan dari sistem keadilan Pemilu, yang secara spesifik dijalankan oleh Sentra Gakkumdu yang didalamnya terdapat unsur-unsur penegak hukum lainnya yakni kepolisian dan kejaksaan dalam menjalankan fungsinya untuk menegakkan keadilan Pemilu.

\subsection{Teori penegakan hukum}

Makna inti dan arti penegakan hukum terletak pada menyerasikan hubungan nilai-nilai yang terjabarkan di dalam kaidah-kaidah yang mantap dan sikap tindak sebagai rangkaian penjabaran nilai tahap akhir untuk menciptakan, memelihara dan mempertahankan kedamaian pergaulan hidup. (Soerjono Soekanto, 2011) Kaedah-kaedah tersebut kemudian menjadi pedoman atau patokan bagi perilaku atau sikap tindak yang dianggap pantas, oleh yang seharusnya. perilaku atau sikap tindak tersebut bertujuan untuk menciptakan, memelihara dan mempertahankan kedamaian.

Dapat disimpulkan bahwa, penegakan hukum bukanlah semata-mata berarti pelaksanaan perundang-undangan, walaupun di dalam kenyataan di Indonesia kecenderungannya adalah demikian, masalah pokok daripada penegakan hukum sebenarnya terletak pada faktorfaktor yang mungkin mempengaruhinya. Faktor-faktor tersebut adalah sebagai berikut: (Soerjono Soekanto, 2011)

a. Faktor hukumnya sendiri, yang di dalamnya dibatasi pada undangundang saja.

b. Faktor penegak hukum, yakni pihakpihak yang membentuk maupun yang menerapkan hukum.

c. Faktor sarana dan prasarana yang mendukung penegak hukum.

d. Faktor masyarakat, yakni lingkungan dimana hukum tersebut berlaku atau diterapkan.

e. Faktor kebudayaan, yakni sebagai 
hasil karya cipta dan rasa yang di dasarkan pada karsa manusia di dalam pergaulan hidup.

Kelima faktor tersebut saling berkaitan dengan erat, karena merupakan esensi dari penegak hukum, juga merupakan tolak ukur dari pada efektifitas penegak hukum. Penegakan hukum sebagaimana dikemukakan Mertokusumo yang dikutip oleh Sajipto Rahardjo mempunyai makna yaitu bagaimana hukum dilaksanakan, sehingga dalam penegakan hukum tersebut harus diperhatikan unsur-unsur kepastian hukum, kemanfaatan dan keadilan. (Sajipto Rahardjo, 1986)

Penegakan hukum adalah suatu proses untuk mewujudkan keinginan keinginan hukum menjadi kenyataan, yang disebut sebagai keinginan hukum di sini tidak lain adalah pikiranpikiran pembuat undang-undang yang dirumuskan dalam peraturan-peraturan hukum itu. Perumusan Pemikiran pembuat undang-undang (hukum) yang dituangkan dalam peraturan hukum akan turut menentukan bagaimana penegakan hukum itu dijalankan.

\section{Hasil dan Pembahasan}

\subsection{Kewenangan, Tugas, dan}

Hambatan Sentra Gakkumdu

Dalam Penegakan Hukum

\section{Pemilu}

\section{- Kewenangan dan Tugas Sentra Gakkumdu}

Merujuk pada Peraturan Bawaslu No. 31/2018 tentang Sentra Penegakkan Hukum Terpadu, Sentra Gakkumdu merupakan pusat dari kegiatan penegakan hukum terhadap tindak pidana Pemilu yang terdiri dari unsur Bawaslu, Polri, dan
Kejaksaan Agung Republik Indonesia (Pasal 1 angka 2 Perbawaslu 31/2018) Walaupun kewenangan penanganan pelanggaran Pemilu terdapat pada Bawaslu, proses penanganan pelanggaran dan tindak pidana Pemilu wajib melewati Sentra Gakkumdu. Jika prosedur dalam Sentra Gakkumdu terlewati, maka penanganan pelanggaran Pemilu cacat prosedur.

Tindak pidana Pemilu itu sendiri terdapat pada Buku Kelima mengenai Tindak Pidana Pemilu, Bab II mengenai Ketentuan Pidana Pemilu sebanyak 66 pasal yaitu dari pasal 488 sampai dengan pasal 554 UU Pemilu, yang antara lain yaitu:

a) Mengacaukan, menghalangi, atau mengganggu jalannya Kampanye Pemilu;

b) Peserta Pemilu yang melakukan Kampanye Pemilu di luar jadwal yang telah ditetapkan oleh KPU;

c) Dengan kekerasan, ancaman kekerasan, atau menggunakan kekuasaan yang ada pada saat pendaftaran Pemilih menghalangi seseorang untuk terdaftar sebagai Pemilih; dan

d) Pada saat pemungutan suara menjanjikan atau memberikan uang atau materi lainnya kepada Pemilih supaya tidak menggunakan hak pilihnya atau memilih Peserta Pemilu tertentu atau menggunakan hak pilihnya dengan cara tertentu sehingga surat suaranya tidak sah (politik uang/money politics).

Kewenangan yang dimiliki oleh Sentra Gakkumdu dalam penanganan tindak pidana Pemilu sebagaimana dimaksud dalam Peraturan Bawaslu No. 31/2018 adalah melakukan penyelidikan, 
penyidikan, penuntutan dan eksekusi terhadap putusan Pengadilan atas tindak pidana Pemilu. Penyelidikan dilakukan sejak Penyidik dan Penuntut Umum Sentra Gakkumdu mendampingi Bawaslu dalam menerima temuan atau laporan tindak pidana Pemilu.(M. Yuhdi, 2014)

Sedangkan tugas Sentra Gakkumdu dalam penanganan tindak pidana Pemilu dimulai dari mendampingi Bawaslu dalam menerima temuan atau laporan dugaan tindak pidana Pemilu. Kemudian, dalam jangka waktu paling lama 1×24 jam sejak laporan tersebut diterima melakukan Pembahasan I untuk memastikan keterpenuhan syarat formil dan syarat materiilnya. Pembahasan itu sendiri adalah kegiatan pada Gakkumdu untuk menindaklanjuti temuan atau laporan dalam rangka penanganan dugaan tindak pidana Pemilu bertujuan menyamakan pendapat dan mengambil keputusan. Terhadap temuan atau laporan tersebut, Bawaslu melakukan pengkajian.

Setelah proses penyelidikan, dilakukan pembahasan II dengan jangka waktu 14 hari kerja sejak temuan atau laporan didaftarkan kemudian dilaksanakan rapat pleno untuk memutuskan apakah akan ditingkatkan ke penyidikan atau tidak. Jika laporan tersebut ditingkat ke porses penyidikan, maka akan diterbitkan Surat Pemberitahuan Dimulainya Penyidikan (SPDP). Terhadap hasil penyidikan tersebut kemudian dilakukan pembahasan III untuk diputuskan apakah akan berlanjut ke penuntutan atau tidak. Kemudian, berkas perkara tersebut dilimpahkan kepada Pengadilan Negeri, sedangkan Penuntutan dilakukan oleh Jaksa Sentra Gakkumdu.

Terhadap putusan pengadilan, Sentra Gakkumdu melakukan pembahasan yang terakhir yaitu pembahasan IV selamalamanya $1 \times 24$ jam setelah putusan pengadilan, yang bertujuan untuk menentukan sikap apakah akan melakukan upaya hukum atau melaksanakan putusan tersebut. Pada tahapan terakhir, Sentra Gakkumdu menjalankan (eksekusi) putusan yang telah mempunyai kekuatan hukum tetap (inkracht van gewisjde) paling lama 3 (tiga) hari setelahnya.

Untuk melakukan tugas dan kewenangannya tersebut, Sentra Gakumdu didukung dengan penempatan personil dari Bawaslu, Kejaksaan, dan Polri. Anggota Bawaslu yang ditempatkan di Sentra Gakkumdu adalah anggota divisi penindakan pelanggaran yang menjabat sebagai leading sector. Sedangkan, Penyidikan dilakukan oleh Penyidik Sentra Gakkumdu dari unsur Polri khususnya Penyidik Tindak Pidana Pemilu pada Bareskrim Polri. Pada tahap penuntutan dan eksekusi dilakukan oleh Penuntut Umum Gakkumdu dari unsur Kejaksaan, tepatnya Jaksa Penuntut Umum (JPU) dibawah Jampidum. Jumlah personil penyidik kepolisian tersebut memiliki Batasan, yakni di tingkat pusat adalah sebanyak 15 orang, pada tingkat provinsi sebanyak 9 orang, dan pada tingkat kabupaten/kota sebanyak 6 orang. Adapun untuk personil dari Kejaksaan memiliki Batasan yakni di tingkat pusat sebanyak 15 orang, pada tingkat provinsi sebanyak 5 orang, dan pada tingkat kabupaten/ kota sebanyak 3 orang. Masing-masing penyidik dan jaksa tersebut berkualifikasi tersendiri, diperbantukan sementara, bekerja penuh waktu, dan tidak diberikan tugas lain oleh lembaga induknya selama bertugas di Sentra Gakkumdu. 
- Hambatan Sentra Gakkumdu

Berdasarkan tugas dan wewenang yang dimiliki, perjalanan Sentra Gakkumdu bukan tanpa hambatan, hal tersebut juga dikatakan oleh Nelson Simanjuntak (Anggota Bawaslu RI Tahun 2012 - 2017), yakni terdapat suatu kecenderungan bahwa penegakan hukum atas pelanggaran pidana pemilu justru tersendat atau terhambat di Sentra Gakkumdu. Sentra Gakkumdu itu sendiri dalam kenyataannya tidak banyak membantu. (2018)

Unsur kepolisian dan kejaksaan yang menjadi bagian dari Sentra Gakkumdu memiliki kekhawatiran tidak dapat memenuhi bukti pemidanaan pelanggaran pemilu, sehingga mereka menjadi sangat defensif dalam menerima laporan tindak pidana pemilu untuk diproses di penyidikan. Masing-masing unsur Sentra Gakkumdu masih memperlakukan Sentra Gakkumdu-nya itu sendiri berdasarkan kepentingan sektoral tiap-tiap Lembaga (tidak secara komprehensif dan menyeluruh). (2018)

Jika berkaca pada Pemilu tahun 2019 lalu, terdapat beberapa kendala dalam operasional Sentra Gakkumdu dalam hal penanganan tindak pidana Pemilu serta eksistensinya itu sendiri secara umum, antara lain yaitu:

1. Masih kurangnya koordinasi dalam penanganan pelanggaran dan penyelesaian tindak pidana Pemilu antara Bawaslu dengan kepolisian dan kejaksaan;

2. Adanya beberapa daerah yang belum memiliki Kepolisian RI Tingkat Provisi (Polda)/ Kepolisian RI Tingkat Kota/Kabupaten (Polres) dan/atau Kejaksaan Tinggi (Kejati)/Kejaksaan Negeri (Kejari) sehingga mengalami kendala dalam koordinasi dengan Polda/Polres dan atau Kejati/Kejari di daerah induk;

3. Kondisi demografis dan geografis serta minimnya peralatan komunikasi di beberapa provinsi/kabupaten/kota yang menghambat kegiatan Sentra Gakkumdu;

4. Masih adanya ketidakpercayaan publik mengenai efektifitas Sentra Gakkumdu;

5. Adanya kelemahan dalam tata kerja dan pola hubungan dalam Sentra Gakkumdu yang membuat penanganan tidak maksmial; dan

6. Adanya subjektifitas tertentu dari unsur-unsur yang ada didalam Sentra Gakkum dalam menangani suatu kasus-kasus tertentu.

\subsection{Dinamika dan Fakta Penegakkan Hukum Pemilu oleh Sentra Gakkumdu}

Setelah dalam subbab sebelumnya dijelaskan mengenai kewenangan, tugas, dan hambatan yang dihadapi oleh Sentra Gakkumdu dalam penanganan dugaan pelanggaran dalam Pemilu 2019 secara teoritis, dalam subbab ini akan menjelaskan secara singkat mengenai dinamika penegakan hukum pemilu dan memberikan contoh kasus penanganan pelanggaran yang dilakukan oleh Sentra Gakkumdu dimana penanganannya menemui hambatan-hambatan sehingga proses penananganannya dapat dikatakan tidak efektif.

Dinamika yang terjadi di lapangan tidaklah semulus teori-teori yang telah disampaikan diatas. Sebagaimana dalam subbagian sebelumnya telah dipaparkan mengenai hambatan-hambatan yang dialami oleh Sentra Gakkumdu ternyata 
dalam praktiknya, terdapat kasus-kasus yang menimbulkan spekulasi ditengah masyarakat, terdapat dua kasus yang penulis paparkan dalam tulisan ini, yaitu pertama kasus yang terjadi di Sulawesi Barat terkait dugaan tindak pidana yang melibatkan 5 (lima) kepala daerah, dan yang kedua yaitu dugaan tindak pidana yang melibatkan 12 (dua belas) kepala daerah di Kota Padang. Menariknya dari kedua kasus tersebut adalah bahwa kedua kasus tersebut sama-sama melibatkan kepala daerah dan terhadap dugaan tindak pidana yang sama yakni dugaan adanya keterlibatan kepala daerah dalam tahapan kampanye, adapun kasus-kasus yang dimaksud adalah sebagai berikut:

- Penghentian kasus deklarasi Gubernur dan 5 (lima) kepala daerah di Sulawesi Barat.

Bahwa kasus tersebut bermula dari temuan Bawaslu Provinsi Sulawesi Barat yang mendapatkan informasi beredarnya video yang berisikan dukungan terhadap salah satu paslon presiden dan wakil presiden yang dilakukan oleh gubernur dan lima kepala daerah di Sulawesi Barat yang diduga melanggara Pasal 547 UU Pemilu. Berdasarkan temuan tersebut diadakan pembahasan pertama Sentra Gakkumdu yang menyimpulkan untuk dilakukan pendalaman kasus sehingga dibutuhkan keterangan saksi dan ahli.

Dalam pembahasan kedua Sentra Gakkumdu Bawaslu Provinsi Sulawesi Barat menyatakan bahwa tindakan tersebut memenuhi konstruksi Pasal 547 UU Pemilu, sedangkan pendapat berbeda disampaikan oleh unsur kepolisian dan kejaksaan di Sentra Gakkumdu, sehingga dalam pembahasan kedua Sentra Gakkumdu mengambil kesimpulan bahwa kasus a quo tidak memenuhi unsur tindak pidana pemilu.

- Penghentian kasus dugaan pelanggaran pada tahapan kampanye yang dilakukan oleh 12 (dua belas) kepala daerah di Kota Padang.

Kasus kedua, yakni dugaan pelanggaran di wilayah Kota Padang. Hal tersebut berawal dari diadakannya kampanye rapat umum salah satu paslon di Kota Padang yang dihadiri oleh dua belas kepala daerah, terhadap hal tersebut Bawaslu Kota Padang melakukan penelusuran atas surat izin cuti dua belas kepala daerah yang mengikuti kampanye rapat umum paslon presiden dan wakil presiden.

Terhadap hasil penelusuran tersebut, Bawaslu Kota Padang menemukan adanya dugaan pelanggaran terhadap Pasal 521 dan 547 UU Pemilu, dan hasil penelusuran tersebut ditingkatkan statusnya menjadi Temuan dan selanjutnya dibahas dalam Sentra Gakkumdu. Dalam pembahasan pertama hingga Sentra Gakkumdu berkesimpulan bahwa temuan a quo tidak memenuhi unsur tindak pidana pemilu, padahal Bawaslu memiliki keyakinan secara nyata bahwa tindakan yang dijadikan temuan tersebut merupakan tindakan yang termasuk tindak pidana pemilu, namun akibat dari adanya ketidaksepahaman diantara unsur Sentra Gakkumdu maka penanganan dugaan tindak pidana tersebut dihentikan.

\subsection{Kritik terhadap mekanisme penanganan dugaan tindak pidana Pemilu dalam Pemilu 2019.}

Setelah dalam dua subbab sebelumnya dijelaskan mengenai hambatan-hambatan yang dialami oleh Sentra Gakkumdu 
dan juga contoh kasus yang penulis uraikan, maka dalam subbab ini mencoba memberikan catatan yang bisa menjadi acuan kedepannya guna menjadikan penegakkan hukum lebih efektif.

Penulis beranggapan muara paling krusial dari semua permasalahan ini adalah bertolak dari dua hal, yakni pemahaman dari masing-masing unsurunsur dalam Sentra Gakkumdu dan kelembagaan Sentra Gakkumdu itu sendiri.

Perbedaan pemahaman antara masing-masing unsur dalam Sentra Gakkumdu merupakan masalah mendasar dari kelemahan penanganan dugaan tindak pidana pemilu dalam Pemilu 2019, hal tersebut menurut penulis dikarenakan masing-masing unsur menggunakan pedoman yang berbeda dalam melihat suatu kasus dugaan tindak pidana pemilu.

Ketiga unsur dalam Sentra Gakkumdu memiliki keyakinan tersendiri atas pedoman yang berasal dari masingmasing instansi yang kemudian harus dilakukan penelitian selanjutnya "apakah pedoman-pedoman tersebut terdapat perbedaan satu dengan yang lainnya?", hal tersebut patut dianalisa lebih lanjut.

Selanjutnya permasalahan yang kedua, terkait desain kelembagaan dari Sentra Gakkumdu itu sendiri. Dibutuhkan suatu desain komperhensif yang dapat digunakan agar dapat memaksimalkan penegakan hukum pemilu. Konsep yang digunakan oleh UU Pemilu untuk Sentra Gakkumdu merupakan hal yang sarat dengan kepentingan didalamnya. Berkumpul tiga lembaga dengan kewenangan yang berbeda diantara ketiganya yang sangat mungkin terjadi gesekan dan dapat mengabaikan keadilan pemilu itu sendiri.
Dalam hal ini perlu suatu konsep yang lebih sederhana daripada mengumpulkan tiga lembaga (Bawaslu, Kepolisian, dan Kejaksaan) dalam satu wadah dengan kekuasaan yang sama, sebagai perbandingan penulis merasa Sentra Gakkumdu perlu mengadopsi struktur organisasi dalam penegakkan hukum di Komisi Pemberantasan Korupsi (KPK), dimana unsur Kepolisian diperbantukan dalam lembaga KPK, sehingga hal tersebut dapat menekan celah mengambil keputusan sesuai kepentingan pribadi atau golongan, dan personil yang ditempatkan akan lebih fokus untuk menangani kasus Pemilu saja, tidak tercampur dengan kewajibannya menangani kasus diluar urusan Pemilu seperti fakta yang terjadi di lapangan.

\section{Simpulan}

Terdapat beberapa hambatan yang dihadapi oleh Sentra Gakkumdu dalam mencapai tujuan untuk menegakkan hukum pemilu. Seperti dicontohkan dari kedua kasus yang dipaparkan dalam bab sebelumnya terlihat bahwa penegakan hukum pemilu masih menjadi "pekerjaan rumah" yang harus segera diselesaikan dalam konteks penyelenggaraan pemilu yang berintegritas. Sehingga di masa depan perlu dilakukan penyamaan persepsi antar unsur di Sentra Gakkumdu.

Kedepan perlu ada perbaikan atas atas dua hal, yakni penyamaan pemahaman antara unsur-unsur di Sentra Gakkumdu dan yang kedua perlu penyempurnaan dari konsep kelembagaan Sentra Gakkumdu. Apabila penyamaan pemahaman dari suatu pasal tindak pidana pemilu tidak dapat dilakukan maka perlu segera dipikirkan terkait konsep baru penegakan pemilu 
yang lebih efektif sehingga pemilu yang berkualitas dan berintegritas dapat terwujud.

Tak kalah penting, usulan untuk mereformasi kelembagaan Sentra Gakkumdu, bahwa penting untuk tidak menempatkan tiga unsur kekuatan dalam satu wadah yang sejajar, hal tersebut tentu memicu adanya ego sektoral yang sangat tinggi sehingga perlu dipikirkan tentang kemungkinan adanya transformasi lembaga Sentra Gakkumdu kedepan.

126 | Jurnal Adhyasta Pemilu 


\section{DAFTAR PUSTAKA}

Amirudin dan Zainal Asikin. (2004). Pengantar Metode Penelitian Hukum. Raja Grafindo Persada. Jakarta.

Djamali, R. Abdoel. (1984). Pengantar Hukum Indonesia. PT. Raja Grafindo Persada. Jakarta.

Kanter, E.Y. dan S. R. Sianturi. (2002). Asas Asas Hukum Pidana di Indonesia dan Penerapannya. Storia Grafika. Jakarta.

Orozco-Henriquez. Keadilan Pemilu: Ringkasan Buku Internasional IDEA. 2010.

Peraturan Badan Pengawas Pemilihan Umum Nomor 31 Tahun 2018 Tentang Sentra Penegakkan Hukum Terpadu

Rahardjo, Satjipto. (1986). Ilmu Hukum. Cetakan Kedua. Alumni, Bandung.

Santoso, Topo. dkk. (2006). Penegakan Hukum Pemilu Praktik Pemilu 2004. Kajian Pemilu 2009-2014. Jakarta: Perludem.

Soekanto, Soerjono. (1986). Pengantar Penelitian Hukum. UI-Press. Jakarta. . (2011). Faktor-Faktor Yang Mempengaruhi Penegakan Hukum. PT. Rajagrafindo Persada. Jakarta.

Soemitro, Ronny Hanitijo. (1983). Metodologi Penelitian Hukum. Jakarta. Ghalia Indonesia.

Sumardjono, Maria S.W. (1989). Pedoman Pembuatan Usulan Penelitian. Fakultas Hukum UGM. Yogyakarta.

Surbakti, Ramlan. dkk. (2011). Penanganan Pelanggaran Pemilu. Jakarta: Kemitraan bagi Pembaruan Tata Pemerintahan.

Sulchan, Achmad. (2014). Rekonstruksi Penegakan Hukum Terhadap Perkara Pidana Pemilihan Umum Berbasis Nilai Keadilan. Jurnal Pembaharuan Hukum. Volume 1 Nomor 3. Sept-Des 2014.

Tim Pengkajian Hukum BPHN. (2015). Laporan Akhir Pengkajian Hukum Tentang Tinjauan Terhadap Efisiensi Pelaksanaan Pemilu Di Indonesia. Jakarta: BPHN. Undang-Undang Nomor 7 Tahun 2017 Tentang Pemilihan Umum.

Yuhdi, M. (2014). Tugas Dan Wewenang Kejaksanaan Dalam Pelaksanaan Pemilihan Umum. Jurnal Pendidikan Pancasila dan Kewarganegaraan. 